\title{
Spotlight on fevipiprant and its potential in the treatment of asthma: evidence to date
}

This article was published in the following Dove Medical Press journal: Journal of Asthma and Allergy

\section{Christina C Kao \\ Amit D Parulekar}

Section of Pulmonary, Critical Care, and Sleep, Department of Medicine, Baylor College of Medicine, Houston, TX, USA
Correspondence: Amit D Parulekar Section of Pulmonary, Critical Care, and Sleep, Department of Medicine, Baylor College of Medicine, 6620 Main Street, Suite IIC. I4, Houston, TX 77030, USA $\mathrm{Tel}+\mathrm{I} 7137986335$

Fax +I 7I37985858

Email paruleka@bcm.edu

\begin{abstract}
Asthma is a heterogeneous disease, which may be classified into phenotypes and endotypes based on clinical characteristics and molecular mechanisms. The best described endotype of severe asthma is type 2 (T2)-high asthma, characterized by release of inflammatory cytokines by $\mathrm{T}$ helper $2\left(\mathrm{~T}_{\mathrm{H}} 2\right)$ cells and type 2 innate lymphoid cells cells. Prostaglandin D2 contributes to T2 inflammation through binding of the G-protein-coupled receptor chemoattractant receptor-homologous molecule expressed on $\mathrm{T}_{\mathrm{H}} 2$ cells (CRTH2). Fevipiprant is an oral competitive antagonist of CRTH2. Early-phase trials have demonstrated safety and potential efficacy in patients with asthma, specifically, improvement in $\mathrm{FEV}_{1}$ and eosinophilic airway inflammation. However, no clear biomarker identified patients who responded favorably to fevipiprant, although patients with moderate-to-severe asthma and evidence of T2 inflammation may be more likely to respond to treatment. Additional studies are needed to determine the efficacy and target population for use of this drug in patients with asthma.
\end{abstract}

Keywords: prostaglandin D2, CRTH2, biologics

\section{Introduction}

Asthma is a chronic inflammatory disease characterized by airway hyperresponsiveness and variable airflow obstruction. Asthma is a heterogeneous disease with variable clinical presentations, underlying mechanisms, and outcomes. The classification of asthma into phenotypes based on clinical characteristics and molecular endotypes based on biologic mechanisms has led to the development of targeted treatments. In particular, these treatments may improve asthma control or decrease asthma exacerbations in patients with severe, uncontrolled asthma despite treatment with inhaled or systemic corticosteroids.

The best described endotype of asthma is type 2 (T2)-high asthma, which is characterized by increased levels of T2 inflammation and occurs in approximately $50 \%$ of patients with severe asthma. ${ }^{1} \mathrm{~T}$ helper $2\left(\mathrm{~T}_{\mathrm{H}} 2\right)$ cells secrete the cytokines IL-4, IL-5, and IL-13, which define T2 inflammation. Along with $\mathrm{T}_{\mathrm{H}} 2$ cells, type 2 innate lymphoid cells (ILC2) also produce IL-5 and IL-13. ${ }^{2}$ IL-4 and IL-13 activities are linked through a shared receptor component and signaling pathway and are involved in $\mathrm{T}_{\mathrm{H}} 2$ cell differentiation and IgE synthesis by B cells. ${ }^{3}$ IL-5 induces growth, survival, and activation of eosinophils. ${ }^{4}$ Presence of eosinophils is important in determining asthma phenotypes ${ }^{5,6}$ and is a consequence of T2 inflammation. Sputum eosinophils are more strongly linked to T2 airway inflammation compared to blood eosinophils. ${ }^{7}$ The molecular pathways of T2-low asthma have not been as well established, but $\mathrm{T}$ helper 17 cells and neutrophils may be key mediators. ${ }^{1}$ 


\section{Prostaglandin D2 metabolism}

Prostaglandin D2 ( $\left.\mathrm{PGD}_{2}\right)$ and its receptor, chemoattractant receptor-homologous molecule expressed on $\mathrm{T}_{\mathrm{H}} 2$ cells (CRTH2), play an important role in T2 inflammation (Figure 1). $T_{H} 2$ cells stimulate IgE isotype switching in $B$ cells, then IgE bound to mast cells binds to antigen, leading to the release of cytokines, leukotrienes, and $\mathrm{PGD}_{2} \cdot{ }^{8} \mathrm{PGD}_{2}$ is produced from the sequential metabolism of arachidonic acid by cyclooxygenase followed by $\mathrm{PGD}_{2}$ synthase. $\mathrm{PGD}_{2}$ is mainly released from mast cells, but platelets, alveolar marcrophages, $\mathrm{T}_{\mathrm{H}} 2$ cells, dendritic cells, and osteoblasts can also produce small amounts of $\mathrm{PGD}_{2} \cdot{ }^{9}$ The effects of $\mathrm{PGD}_{2}$ are mediated by G-protein-coupled receptors. $\mathrm{PGD}_{2}$ activates two receptors: the DP (PGD) receptor and CRTH2. CRTH2 is expressed on $\mathrm{T}_{\mathrm{H}} 2$ cells, eosinophils, basophils, and ILC2 cells. ${ }^{10,11}$ Although CRTH2 binds PGD $_{2}$ with approximately equal affinity as the DP receptor, it shows little similarity to the DP receptor and is more closely related to other chemoattractant receptors. ${ }^{12}$

$\mathrm{PGD}_{2}$ can function as both a pro- and anti-inflammatory mediator, depending on ligand affinity, receptor expression profile, and cellular context in which the receptor is expressed. ${ }^{13} \mathrm{PGD}_{2}$ is responsible for allergic inflammation, likely via both the DP receptor and the CRTH2 receptor. The DP receptor is expressed on bronchial epithelial cells, and binding of mast-cell-derived $\mathrm{PGD}_{2}$ to $\mathrm{DP}$ in the epi- thelium stimulates production and release of cytokines and chemokines that recruit $\mathrm{T}_{\mathrm{H}} 2$ lymphocytes, leading to airway inflammation, airflow obstruction, and airway hyperreactivity. ${ }^{14} \mathrm{PGD}_{2}$ also mediates recruitment of eosinophils and basophils via the CRTH2 receptor ${ }^{12}$ and inhibits eosinophil apoptosis via the DP receptor. ${ }^{15} \mathrm{PGD}_{2}$ induces rapid change in eosinophil morphology and an increase in eosinophil chemokinesis. ${ }^{15} \mathrm{PGD}_{2}$ activation of DP has an opposite effect on basophils by inhibiting basophil migration and IgE-mediated degranulation. ${ }^{9} \mathrm{PGD}_{2}$ is also a potent bronchoconstrictor via the thromboxane A2 (TP) receptor, although $\mathrm{PGD}_{2}$ has low affinity to the TP receptor. ${ }^{16} \mathrm{PGD}_{2}-\mathrm{CRTH} 2$ interaction may also stimulate ILC2 migration leading to T2 inflammation in the lung. ${ }^{17}$

\section{PGD $_{2}-$ CRTH2 activity in asthma}

$\mathrm{PGD}_{2}$ levels have been measured in patients with asthma with inconsistent results. In patients with mild asthma, levels of $\mathrm{PGD}_{2}$ in bronchoalveolar lavage (BAL) have been shown to be increased ${ }^{18,19}$ and no different ${ }^{20,21}$ compared to nonasthmatics. However, all of these studies had small numbers of patients. Patients with severe asthma had increased BAL fluid $\mathrm{PGD}_{2}$ compared to patients with mild/moderate asthma receiving inhaled corticosteroids. ${ }^{22}$ This finding was later confirmed in an expansion of this cohort of patients with asthma. ${ }^{23} \mathrm{BAL}$ fluid $\mathrm{PGD}_{2}$ was inversely associated with lung
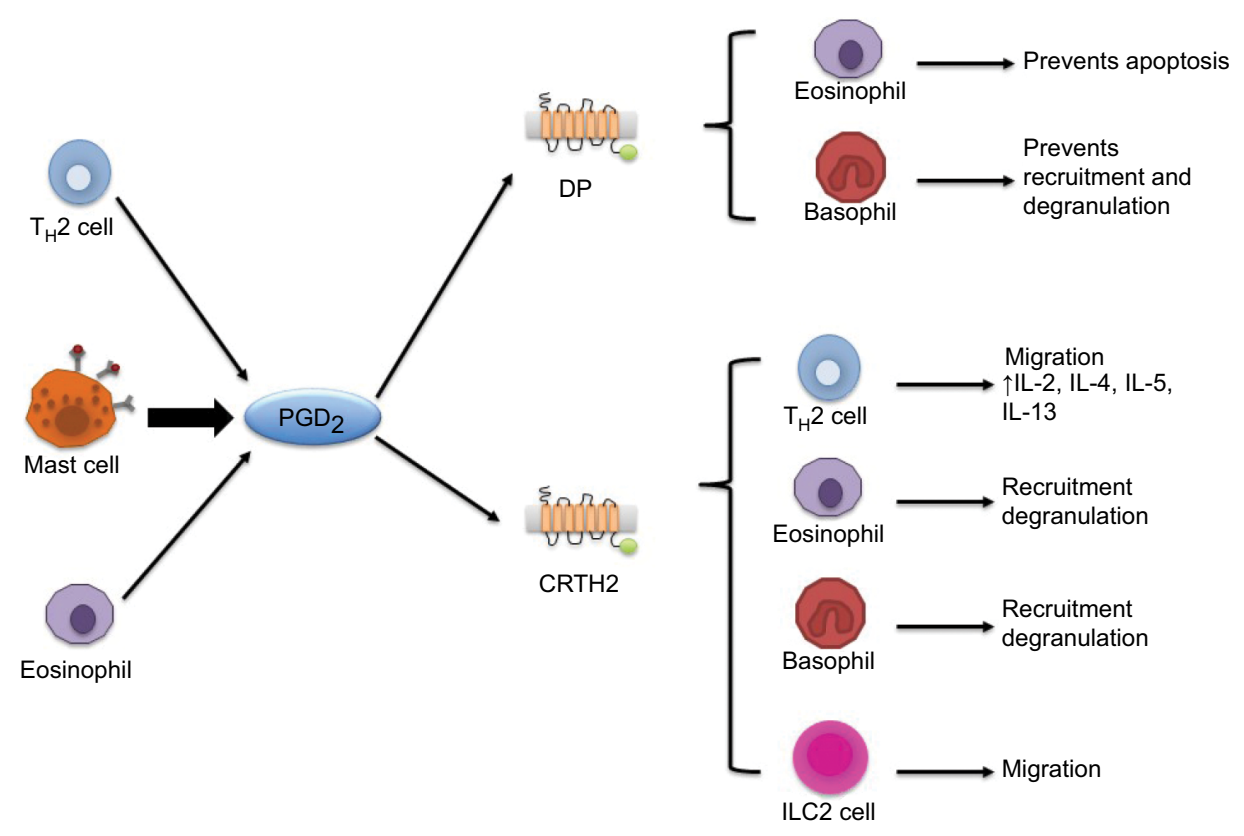

Figure I Role of $\mathrm{PGD}_{2}$ in asthma.

Notes: $P_{G D}$ is mainly released from mast cells after mast cell degranulation mediated by $\lg E$, but $T_{H} 2$ cells and eosinophils can also release small amounts of $P G D_{2}$. The effects of PGD are mediated by two G-protein-coupled receptors, the DP receptor and CRTH2. PGD 2 binding to PD inhibits eosinophil apoptosis and inhibits basophil migration and lgE-mediated degranulation. $P_{G} D_{2}$ binding to $C R T H 2$ stimulates production and release of cytokines leading to $T_{H} 2$ recruitment as well as recruitment and degranulation of eosinophils and basophils. $\mathrm{PGD}_{2}-\mathrm{CRTH} 2$ interaction may also stimulate type 2 inflammation via migration of ILC2 cells.

Abbreviations: CRTH2, chemoattractant receptor-homologous molecule expressed on $\mathrm{T}_{\mathrm{H}} 2$ cells; DP, prostaglandin D receptor; ILC2, type 2 innate lymphoid cell; PGD, prostaglandin $\mathrm{D} 2 ; \mathrm{T}_{\mathrm{H}} 2, \mathrm{~T}$ helper cell type 2 . 
function and positively correlated with worse symptoms and a history of recent exacerbation. $\mathrm{PGD}_{2}$ levels also increase in patients with asthma following allergen challenge. ${ }^{20,24}$

Expression of the CRTH2 receptor on T cells is also different in patients with asthma compared to healthy controls. CRTH2+ T cells composed only a small population of cells in BAL fluid, but there was a significantly greater percentage in patients with asthma compared to controls. ${ }^{21}$ In another study, CRTH2 mRNA levels in BAL were highest in patients with severe asthma compared to patients with mild asthma not treated with ICS and healthy controls. ${ }^{23}$ Higher BAL fluid PGD $_{2}$ levels and CRTH2+ cell numbers were associated with poor asthma control, peripheral blood eosinophilia, and high exhaled nitric oxide (FeNO) levels. Overall, these studies suggest that increased $\mathrm{PGD}_{2}$ levels and CRTH2 expression are seen in patients with more severe, T2 asthma.

\section{Overview of fevipiprant}

Fevipiprant (QAW039; [(2-[2-methyl-1-(4-[methylsulfonyl]2-[trifluoromethyl]benzyl)-1H-pyrrolo(2,3-b)pyridine-3-yl] acetic acid)]) is an oral, highly selective, potent, reversible competitive antagonist of CRTH2. Fevipiprant is metabolized to an inactive acyl-glucoride metabolite. Elimination of fevipiprant occurs via hepatic metabolism as well as renal excretion. $^{25}$

\section{Clinical studies of fevipiprant}

A Phase I study evaluated the pharmacokinetics and safety of a range of doses of fevipiprant given as single and multiple doses in 48 healthy volunteers. ${ }^{26}$ Peak concentrations of fevipiprant were observed 1-3 hours after dosing with a half-life of approximately 18-20 hours. Fevipiprant was well tolerated, and the adverse events were similar between fevipiprant and placebo. There were no significant adverse events or death, and the most common side effects were headache and nasal congestion.

In a Phase II study, 170 patients with mild-to-moderate persistent, allergic asthma were randomized to receive fevipiprant $500 \mathrm{mg}$ daily for 28 days ( 82 patients, 75 completed the study) or placebo ( 88 patients, 82 completed the study). ${ }^{27}$ There was no difference in the primary outcome, mean trough $\mathrm{FEV}_{1}$, between the groups. In the predefined subgroup of patients with $\mathrm{FEV}_{1}$ percent predicted $<70 \%$, there was significant improvement in trough $\mathrm{FEV}_{1}$ as well as asthma control questionnaire (ACQ7) in patients treated with fevipiprant compared to placebo. In patients with high serum IgE and blood eosinophils $>300 / \mu \mathrm{L}$ and patients with FeNO $>$ median, there was a significant improvement in
$\mathrm{FEV}_{1} \mathrm{AUC}_{0-24}$ (the area under the effect curve from 0 to 24 hours).

In a Phase II study, Gonem et $\mathrm{al}^{28}$ randomized 61 patients with moderate-to-severe, persistent asthma and sputum eosinophilia ( $\geq 2 \%$ ) to receive fevipiprant $225 \mathrm{mg}$ orally twice daily or placebo for 12 weeks. The geometric mean sputum eosinophil percentage decreased from 5.4 to 1.1 in the fevipiprant group and from 4.6 to 3.9 in the placebo group. Thus, treatment with fevipiprant resulted in a significant, 3.5-fold greater decrease in sputum eosinophilia than placebo. In addition, fevipiprant reduced bronchial submucosal eosinophil numbers in bronchial biopsy samples compared to placebo. However, there was no change in blood eosinophil count. Change in mean asthma control measured by ACQ7 was not different between the groups except in the subgroup of patients with uncontrolled asthma at baseline.

In a Phase IIB study, Bateman et $\mathrm{al}^{29}$ randomized 1,058 adult patients with allergic asthma that was uncontrolled with inhaled corticosteroids to once-daily fevipiprant ( 9 doses ranging from 1 to $450 \mathrm{mg}$ ), twice-daily fevipiprant (4 doses ranging from 2 to $150 \mathrm{mg}$; 782 total patients assigned to fevipiprant), montelukast (139 patients), or placebo (137 patients). Patients were maintained on budesonide $200 \mu \mathrm{g}$ BID during the 12-week treatment period. There was an improvement in predose $\mathrm{FEV}_{1}$ with both fevipiprant and montelukast compared to placebo. There was no evidence of a higher efficacy in any predefined subgroup, including blood eosinophil count, predicted $\mathrm{FEV}_{1}$, or baseline ACQ scores. Fevipiprant did not improve asthma symptom control.

In all the Phase II studies, fevipiprant had acceptable safety and tolerability. The variable efficacy of fevipiprant in these Phase II studies is likely related to differences in patient populations in terms of asthma severity, asthma control, and presence of eosinophilia. The optimal target population for fevipiprant is yet to be identified, but may be patients with severe eosinophilic asthma. ${ }^{30}$ Several biologic drugs are currently available for the treatment of severe, eosinophilic asthma including the IL-5 inhibitors mepolizumab and reslizumab, the IL-5 receptor antagonist benralizumab, and the IL-13/IL-4 inhibitor dupilumab. Because fevipiprant is orally administered, it may be an attractive alternative for patients with uncontrolled eosinophilic asthma. However, further studies are needed to determine if fevipiprant improves clinical outcomes such as symptom scores, asthma control, and exacerbation risk in addition to improving lung function and sputum eosinophilia. See Table 1 for summary of clinical trials. 
Table I Phase II clinical studies of fevipiprant in patients with asthma

\begin{tabular}{|c|c|c|c|c|c|}
\hline Author & Fevipiprant dose & Type of study & Patients & Outcomes & $\begin{array}{l}\text { Biomarkers } \\
\text { identifying response }\end{array}$ \\
\hline $\begin{array}{l}\text { Erpenbeck et al } \\
(2016)^{27}\end{array}$ & $\begin{array}{l}500 \mathrm{mg} \text { once daily } \times 28 \\
\text { days }\end{array}$ & Phase II RCT & $\begin{array}{l}\text { I } 70 \text { patients with mild-to- } \\
\text { moderate asthma with a } \\
\text { positive skin prick test to } \\
\text { local allergens }\end{array}$ & $\begin{array}{l}\text { No difference in trough FEV, } \\
\text { or symptom scores }\end{array}$ & $\begin{array}{l}\text { Improvement in trough } \\
\mathrm{FEV} \text {, in patient with } \\
\text { baseline } \mathrm{FEV}_{1}<70 \% \\
\text { predicted }\end{array}$ \\
\hline $\begin{array}{l}\text { Gonem et al } \\
(2016)^{28}\end{array}$ & $\begin{array}{l}\text { Fevipiprant } 225 \mathrm{mg} \\
\text { orally twice daily versus } \\
\text { placebo }\end{array}$ & $\begin{array}{l}\text { Single center } \\
\text { RCT }\end{array}$ & $\begin{array}{l}6 \text { I patients with moderate- } \\
\text { to-severe asthma and } \\
\text { sputum eosinophil count } \\
\text { of } \geq 2 \%\end{array}$ & $\begin{array}{l}\downarrow \text { in sputum eosinophil } \\
\text { counts } \\
\text { Improvement in post- } \\
\text { bronchodilator FEV }\end{array}$ & \\
\hline $\begin{array}{l}\text { Bateman et al } \\
(2017)^{29}\end{array}$ & $\begin{array}{l}\text { Fevipiprant once or } \\
\text { twice daily, montelukast, } \\
\text { or placebo } \times 12 \text { weeks }\end{array}$ & Phase Ilb RCT & $\begin{array}{l}\text { I058 patients with allergic } \\
\text { asthma inadequately } \\
\text { controlled with ICS }\end{array}$ & $\begin{array}{l}\text { Improvement in FEV } \\
\text { No difference in asthma } \\
\text { symptom control }\end{array}$ & $\begin{array}{l}\text { No difference based on } \\
\text { blood eosinophils }\end{array}$ \\
\hline
\end{tabular}

Abbreviations: $\mathrm{FEV}_{1}$ - forced expiratory volume in I second; RCT - randomized control trial.

\section{Ongoing clinical studies}

There are several ongoing Phase III clinical studies of fevipiprant in patients with asthma. LUSTER 1 and 2 (ClinicalTrials.gov, NCT02555683 and NCT02563067) will determine the safety of fevipiprant as well as its effect on rate of asthma exacerbations in patients with severe, uncontrolled asthma. The ZEAL1 and ZEAL2 studies (ClinicalTrials. gov, NCT03215758 and NCT03226392) will determine the efficacy and safety of fevipiprant in patients with moderate, uncontrolled asthma receiving ICS. The primary endpoint will be change from baseline in predose $\mathrm{FEV}_{1}$ after 12 weeks. NCT03052517 is a study to assess the long-term safety of fevipiprant compared to placebo in patients with moderateto-severe asthma.

A number of other CRTH2 receptor antagonists have been investigated in asthma. Those studied in clinical trials include AZD1981, ${ }^{31}$ OC000459, ${ }^{32,33}$ setipiprant,,${ }^{34}$ and BI671800. ${ }^{35}$ In addition, AMG853 is a dual CRTH2 and DP receptor antagonist. ${ }^{36}$ Some studies of these agents demonstrated significant improvement in lung function and quality of life, ${ }^{32,33,35}$ while others showed no difference. ${ }^{31,36}$

\section{Conclusion}

Asthma is a heterogeneous disease with a significant health care burden, especially among patients with severe, uncontrolled disease. Improved understanding of asthma phenotypes and endotypes has provided the opportunity to better tailor approaches to individual patients. Multiple biologic treatments have recently been approved by the Food and Drug Administration for the treatment of eosinophilic asthma. Fevipiprant, an oral, reversible competitive antagonist of CRTH2, has shown promise in early-phase trials in patients with asthma. Ongoing Phase III clinical studies should shed further light on the potential benefit of fevipiprant in patients with uncontrolled, moderate-tosevere asthma. Demonstrating reproducible benefit as well as defining and refining the target treatment population remains necessary for this drug to gain approval for clinical use. For now, we are left with the potential of an oral drug targeting asthma patients with severe or difficult-tocontrol disease.

\section{Disclosure}

The authors report no conflicts of interest in this work.

\section{References}

1. Wenzel SE. Emergence of biomolecular pathways to define novel asthma phenotypes. Type-2 immunity and beyond. Am J Respir Cell Mol Biol. 2016;55(1):1-4.

2. Parulekar AD, Diamant Z, Hanania NA. Role of T2 inflammation biomarkers in severe asthma. Curr Opin Pulm Med. 2016;22(1):59-68.

3. Parulekar AD, Kao CC, Diamant Z, Hanania NA. Targeting the interleukin-4 and interleukin-13 pathways in severe asthma: current knowledge and future needs. Curr Opin Pulm Med. 2018;24(1):50-55.

4. Takatsu K, Nakajima H. IL-5 and eosinophilia. Curr Opin Immunol. 2008;20(3):288-294.

5. Moore WC, Meyers DA, Wenzel SE, et al; National Heart, Lung, and Blood Institute's Severe Asthma Research Program. Identification of asthma phenotypes using cluster analysis in the severe asthma research program. Am J Respir Crit Care Med. 2010;181(4):315-323.

6. Siroux V, Basagaña X, Boudier A, et al. Identifying adult asthma phenotypes using a clustering approach. Eur Respir J. 2011;38(2):310-317.

7. Gauthier M, Ray A, Wenzel SE. Evolving concepts of asthma. Am J Respir Crit Care Med. 2015;192(6):660-668.

8. Levine SJ, Wenzel SE. Narrative review: the role of Th2 immune pathway modulation in the treatment of severe asthma and its phenotypes. Ann Intern Med. 2010;152(4):232-237.

9. Kostenis E, Ulven T. Emerging roles of DP and CRTH2 in allergic inflammation. Trends Mol Med. 2006;12(4):148-158.

10. Nagata K, Hirai H, Tanaka K, et al. CRTH2, an orphan receptor of T-helper-2-cells, is expressed on basophils and eosinophils and responds to mast cell-derived factor(s). FEBS Lett. 1999;459(2):195-199. 
11. Xue L, Salimi M, Panse I, et al. Prostaglandin D2 activates group 2 innate lymphoid cells through chemoattractant receptor-homologous molecule expressed on TH2 cells. J Allergy Clin Immunol. 2014;133(4):1184-1194.

12. Hirai H, Tanaka K, Yoshie O, et al. Prostaglandin D2 selectively induces chemotaxis in T helper type 2 cells, eosinophils, and basophils via seventransmembrane receptor CRTH2. J Exp Med. 2001;193(2):255-262.

13. Hata AN, Breyer RM. Pharmacology and signaling of prostaglandin receptors: multiple roles in inflammation and immune modulation. Pharmacol Ther. 2004;103(2):147-166.

14. Kabashima K, Narumiya S. The DP receptor, allergic inflammation and asthma. Prostaglandins Leukot Essent Fatty Acids. 2003;69(2-3):187-194.

15. Gervais FG, Cruz RP, Chateauneuf A, et al. Selective modulation of chemokinesis, degranulation, and apoptosis in eosinophils through the PGD2 receptors CRTH2 and DP. J Allergy Clin Immunol. 2001;108(6):982-988.

16. Johnston SL, Bardin PG, Harrison J, Ritter W, Joubert JR, Holgate $\mathrm{ST}$. The effects of an oral thromboxane TP receptor antagonist BAY u 3405, on prostaglandin D2- and histamine-induced bronchoconstriction in asthma, and relationship to plasma drug concentrations. $\mathrm{Br} \mathrm{J}$ Clin Pharmacol. 1992;34(5):402-408.

17. Wojno ED, Monticelli LA, Tran SV, et al. The prostaglandin D2 receptor CRTH2 regulates accumulation of group 2 innate lymphoid cells in the inflamed lung. Mucosal Immunol. 2015;8(6):1313-1323.

18. Crea AE, Nakhosteen JA, Lee TH. Mediator concentrations in bronchoalveolar lavage fluid of patients with mild asymptomatic bronchial asthma. Eur Respir J. 1992;5(2):190-195.

19. Liu MC, Bleecker ER, Lichtenstein LM, et al. Evidence for elevated levels of histamine, prostaglandin D2, and other bronchoconstricting prostaglandins in the airways of subjects with mild asthma. Am Rev Respir Dis. 1990;142(1):126-132.

20. Wenzel SE, Westcott JY, Smith HR, Larsen GL. Spectrum of prostanoid release after bronchoalveolar allergen challenge in atopic asthmatics and in control groups. An alteration in the ratio of bronchoconstrictive to bronchoprotective mediators. Am Rev Respir Dis. 1989;139(2):450-457.

21. Mutalithas K, Guillen C, Day C, Brightling CE, Pavord ID, Wardlaw AJ. CRTH2 expression on T cells in Asthma. Clin Exp Immunol. 2010;161(1):34-40.

22. Balzar S, Fajt ML, Comhair SA, et al. Mast cell phenotype, location, and activation in severe asthma. Data from the severe asthma research program. Am J Respir Crit Care Med. 2011;183(3):299-309.

23. Fajt ML, Gelhaus SL, Freeman B, et al. Prostaglandin D2 pathway upregulation: relation to asthma severity, control, and $\mathrm{TH} 2$ inflammation. J Allergy Clin Immunol. 2013;131(6):1504-1512.
24. Murray JJ, Tonnel AB, Brash AR, et al. Release of prostaglandin D2 into human airways during acute antigen challenge. $N$ Engl J Med. 1986;315(13):800-804.

25. Pearson D, Weiss HM, Jin Y, et al. Absorption, distribution, metabolism, and excretion of the oral prostaglandin D2 receptor 2 antagonist fevipiprant (QAW039) in healthy volunteers and in vitro. Drug Metab Dispos. 2017;45(7):817-825.

26. Erpenbeck VJ, Vets E, Gheyle L, et al. Pharmacokinetics, safety, and tolerability of fevipiprant (QAW039), a novel CRTh2 receptor antagonist: results from 2 randomized, phase 1, placebo-controlled studies in healthy volunteers. Clin Pharmacol Drug Dev. 2016;5(4):306-313.

27. Erpenbeck VJ, Popov TA, Miller D, et al. The oral CRTh2 antagonist QAW039 (fevipiprant): a phase II study in uncontrolled allergic asthma. Pulm Pharmacol Ther. 2016;39:54-63.

28. Gonem S, Berair R, Singapuri A, et al. Fevipiprant, a prostaglandin D2 receptor 2 antagonist, in patients with persistent eosinophilic asthma: a single-centre, randomised, double-blind, parallel-group, placebocontrolled trial. Lancet Respir Med. 2016;4(9):699-707.

29. Bateman ED, Guerreros AG, Brockhaus F, et al. Fevipiprant, an oral prostaglandin $\mathrm{DP}_{2}$ receptor $\left(\mathrm{CRTh}_{2}\right)$ antagonist, in allergic asthma uncontrolled on low-dose inhaled corticosteroids. Eur Respir J. 2017;50(2):1700670.

30. Brusselle GG, Provoost S, Maes T. Prostaglandin D2 receptor antagonism: a novel therapeutic option for eosinophilic asthma? Lancet Respir Med. 2016;4(9):676-677.

31. Kuna P, Bjermer L, Tornling G. Two Phase II randomized trials on the CRTh2 antagonist AZD1981 in adults with asthma. Drug Des Devel Ther. 2016;10:2759-2770.

32. Barnes N, Pavord I, Chuchalin A, et al. A randomized, double-blind, placebo-controlled study of the CRTH2 antagonist OC000459 in moderate persistent asthma. Clin Exp Allergy. 2012;42(1):38-48.

33. Pettipher R, Hunter MG, Perkins CM, et al. Heightened response of eosinophilic asthmatic patients to the CRTH2 antagonist OC000459. Allergy. 2014;69(9):1223-1232.

34. Diamant Z, Sidharta PN, Singh D, et al. Setipiprant, a selective CRTH2 antagonist, reduces allergen-induced airway responses in allergic asthmatics. Clin Exp Allergy. 2014;44(8):1044-1052.

35. Hall IP, Fowler AV, Gupta A, et al. Efficacy of BI 671800, an oral CRTH2 antagonist, in poorly controlled asthma as sole controller and in the presence of inhaled corticosteroid treatment. Pulm Pharmacol Ther. 2015;32:37-44.

36. Busse WW, Wenzel SE, Meltzer EO, et al. Safety and efficacy of the prostaglandin D2 receptor antagonist AMG 853 in asthmatic patients. J Allergy Clin Immunol. 2013;131(2):339-345.
Journal of Asthma and Allergy

\section{Publish your work in this journal}

The Journal of Asthma and Allergy is an international, peer-reviewed open access journal publishing original research, reports, editorials and commentaries on the following topics: Asthma; Pulmonary physiology; Asthma related clinical health; Clinical immunology and the immunological basis of disease; Pharmacological interventions and new therapies. This journal is included in PubMed. The manuscript management system is completely online and includes a very quick and fair peer-review system, which is all easy to use. Visit http://www. dovepress.com/testimonials.php to read real quotes from published authors. 